\title{
PENGARUH E-MONEY DAN E-COMMERCE TERHADAP TINGKAT INFLASI
}

\author{
Siti Rahmayuni \\ Manajemen, Sekolah Tinggi Ilmu Ekonomi Balikpapan \\ Jl. Guntur Damai no 166 Balikpapan, 76123 \\ E-mail : sitirahmayuni@stie-balikpapan
}

\begin{abstract}
ABSTRAK
Perkembangan teknologi berpengaruh terhadap kehidupan masyarakat, baik itu gaya hidup maupun ekonomi, dimana banyaknya bermunculan e money seperti kartu kredit dan aplikasi aplikasi pendukung e money, dan e commerce seperti shopee, tokopedia dan lainnya, Penelitian ini bertujuan untuk mengetahui pengaruh e money dan e commerce terhadap tingkat inflasi, metode penelitian ini menggunakan deskriptif kuantitatif. Populasi dan sample sebanyak 50 responden. Teknik analisa data yang digunakan pada penelitian ini adalah deskriptif kuantitatif dan regresi linear bergandadengan hasil penelitian menujukkan dengan uji $\mathrm{F}$ ditemukan bahwa E Money dan E Commerce berpengaruh terhadap inflasi dengan nilai 3,39 dan nilai koefisien 0.153 dan pada uji t E-Money menunjukkan nilai signifikan dengan jumlah nilai $13,28>3,88$ serta signifikan $0,000<0,0005$ dan pada E-Comerce dengan nilai 63,1 dengan nilai koefisien regresi bernilai positif yaitu sebesar 0,499 dan uji t pada E-Commerce menunjukan nilai thitung lebih besar dari pada nilai t tabel yaitu $7,123>2,040$ serta nilai Sig. 0,000 < 0,05, pengaruh tersebut dapat dijadikan kebijakan bagi Bank Indonesia untuk mengantisipasi tingkat inflasi yang bertambah dengan adanya E-money dan E-comerce
\end{abstract}

Kata Kunci: E Money, E Commerce dan Inflasi

\section{PENDAHULUAN}

Perkembangan teknologi berpengaruh terhadap kehidupan masyarakat, baik itu gaya hidup maupun ekonomi, dimana banyaknya bermunculan e money seperti kartu kredit dan aplikasi aplikasi pendukung e money, dan e commerce seperti shopee, tokopedia dan lainnya. Hal ini didukung dengan dengan kebutuhan manusia yang semakin bervariatif, pembayaran dengan menggunakan pembayaran elektronik ( emoney) sangat memudahkan masyarakat karena tidak harus membawa uang yang banyak untuk ke store yang tersedia. Cukup membawa kartu ATM, kartu kredit dan handphone dimana didalamnya dapat menggunakan fasilitas yang disediakan oleh bank, begitu juga dengan adanya e commerce memudahkan masyarakat untuk berbelanja tanpa harus datang ketempat perbelanjaan ataupun pasar.

Berdasarkan ketentuan Peraturan Bank Indonesia Nomor 20/06/ PBI/ 2018 tentang uang elektronik (EMoney) yaitu alat pembayaran yang diterbitkan atas dasar nilai uang yang disetor terlebih dahulu oleh pemegang kepada penerbit. Nilai uang disimpan secara elektronik dalam sebuah media aplikasi atau dalam bentuk kartu yang digunakan sebagai alat pembayaran yang sah kepada pedagang penyedia mesin pembayaran namun bukan sebagai penerbit kartu atau uang elektronik,

E Commerce merupakan transaksi antara pembeli dan penjual dengan pertukaran jasa dan barang melalui media yang sudah di tersedia oleh para pembuat lapak menggunakan jaringan internet dengan metode pembayaran less cash, melalui Elektronik Fund Transfer
(EFT), Internet Banking, Mobile Banking Anjungan Tunai Mandiri (ATM) dll.

Dengan adanya e money dan e commerce dapat mempengaruhi tingkat inflasi. Inflasi diartikan sebagai kenaikan harga secara umum dan terus menerus dalam jangka waktu tertentu. maka inflasi mengalami kenaikan.

S. Sukirno (2002) Mengungkapkan Bahwa Inflasi Ialah Suatu Proses Ketika Terjadinya Suatu Kenaikan Harga Yang Berlaku Terhadap Perekonomian.

Laju inflasi yang terkendali akan menambah keuntungan pengusaha, pertambahan keuntungan akann menggalakkan investasi di masa datang dan pada akhirnya akan mempercepat terciptanya pertumbuhan ekonomi. Sebaliknya tingkat inflasi yang tinggi akan berdampak negatif pada perekonomian yang selanjutnya dapat mengganggu kestabilan sosial dan politik. Dampak negative pada perekonomian diantaranya mengurangi kegairahan penanam modal, tidak terjadinya pertumbuhan ekonomi, memperburuk distribusi pendapatan dan mengurangi daya beli masyarakat.

Oleh karena itu perlu diupayakan jangan sampai penyakit ekonomi itu menjadi penghambat jalannya roda pembangunan.

Berdasarkan beberapa teori dasar tentang inflasi tersebut berbagai penelitian mengenai inflasi telah dilakukan di banyak negara, baik di negara maju maupun di negara berkembang. Jika diklasifikasikan secara umum maka inflasi dapat dilihat dari berbagai sudut pandang berdasarkan faktor penyebabnya, inflasi dapat berasal sisi permintaan (demand-side inflation), inflasi yang berasal dari sisi penawaran (supply-side inflation) atau kombinasi dari keduanya (demand-supply inflation). 
Dari sisi penawaran penyebab inflasi misalnya adalah karena kenaikan upah (wage cost push inflation) dan kenaikan harga barang-barang impor (import cost inflation). Sementara itu, dari sisi permintaan disebabkan oleh kenaikan permintaan yang tidak diimbangi oleh penawaran (demand pull inflation).

Adrian Sutawijaya (2012) Pengaruh Faktor-Faktor Ekonomi Terhadap Inflasi Di Indonesia Inflasi yaitu mendapat perhatian khusus dalam perekonomian Indonesia. Setiap kali ada distorsi di masyarakat, politik atau ekonomi, orang selalu mengaitkannya dengan inflasi. Tingkat inflasi yang rendah dan stabil akan menjadi inflasi stimulator pertumbuhan ekonomi. Variabel yang akan diteliti dalam penelitian ini adalah tingkat suku bunga, investasi, uang beredar, dan nilai tukar. Penelitian ini menggunakan data dari Badan Pusat Statistik (BPS) dan Bank Indonesia (BI) antara 19852005. Data penelitian dianalisis dengan menggunakan OLS (Ordinary Least Square). Studi ini menunjukkan bahwa tingkat suku bunga, jumlah uang beredar, investasi, dan nilai tukar secara simultan mempengaruhi inflasi di Indonesia. Tingkat bunga memiliki pengaruh positif $1,289 \%$. Uang beredar akan memiliki pengaruh positif terhadap inflasi $0,001 \%$. Investasi berdampak negatif inflasi,$- 0001802 \%$. Kurs memiliki dampak positif pada inflasi $0,00427 \%$.

A.H.G.M. Spithoven (1995) Human capital inflation and unemployment, Menyatakan bahwa persetujuan dari banyak pengangguran dengan inflasi tidak menghasilkan ide-ide baru dan bahwa pemerintah mendalilkan bahwa pengeluaran berlebihan, pembayaran jaminan sosial khususnya, adalah penyebab utama keduanya: kebijakan moneter dan fiskal ketat restriktif yang sah ini, tetapi hasil yang diharapkan gagal muncul. Menemukan bahwa inflasi memang mereda tetapi peningkatan pengangguran tidak. Menyarankan bahwa, karena layanan yang diperlukan untuk meningkatkan sumber daya manusia adalah prasyarat untuk kemajuan ekonomi, maka negara harus menjamin setidaknya kondisi minimum untuk akses siap ke layanan. Untuk pemerintah yang menghitung, ini sulit diimplementasikan. Itulah sebabnya prinsip penghitungan yang mendominasi dalam politik (semacam sikap pembukuan monetaris) merusak kinerja ekonomi suatu negara dan mengancam demokrasi. Namun kerangka ekonomi moneter tetap ada. Selain itu, menunjukkan Perjanjian Maastricht benarbenar menetapkan kerangka hukum dan ekonomi dimana stabilitas harga lebih diutamakan daripada pertumbuhan, pengurangan pengangguran dan pertimbangan kesejahteraan sosial. Merasa bahwa pemeriksaan ulang tentang penyebab sebenarnya dari inflasi dan pengangguran telah menjadi keharusan.

Rui Qin (2017) The Impact of Money Supply and Electronic Money: Empirical Evidence from Central Bank in China menunjukkan dalam model teoritis ilustratif bahwa uang elektronik akan berdampak pada jumlah uang beredar, terutama mempengaruhi M0 dan M1. Menggunakan data bank sentral di Tiongkokselama
1990 hingga 2010 dan menerapkan model regresi kuadrat terkecil (OLS), kami menemukan kuat bukti bahwa uang elektronik memiliki dampak negatif pada M0, tetapi berdampak positif pada M1. Di Selain itu, kemampuan bank sentral untuk mengendalikan jumlah uang beredar dapat dipengaruhi secara luas penerapan uang elektronik. Selanjutnya, hasil ini dapat membantu bank sentral dan keuangan lembaga memprediksi lingkungan ekonomi dan mengambil tindakan yang diperlukan, menghilangkannya mempengaruhi dan memperkuat stabilitas pasar uang.

Frida Calson-Ohman (2018) The Effect Of Increased E-Commerce On Inflation, yaitu model regresi efek tetap diterapkan, berdasarkan data panel untuk 28 Eropa negara untuk periode waktu 2006-2017. Regresi memperoleh hasil yang mendukung hipotesis bahwa peningkatan e-commerce memiliki efek negatif pada inflasi. Selanjutnya, hasilnya menunjukkan bahwa efeknya berkurang dari Model Koreksi Kesalahan dan data deret waktu untuk Swedia selama periode 20062017. Hasilnya menunjukkan bahwa ada koreksi kesalahan menuju keseimbangan jangka panjang dan pendek estimasi jangka menunjukkan bahwa ada efek negatif jangka pendek dari peningkatan e-commerce tentang inflasi

Nastiti, Nisaulfathona, dkk (2017) Analisis Pengaruh Instrumen Pembayaran Nontunai Terhadap Stabilitas Sistem Keuangan Di Indonesia menunjukkan Bahwa EMoney Dan Kartu Kredit transaksi berpengaruh positif signifikan pada M1, transaksi e-money berpengaruh signifikan efek negatif pada suku bunga, dan transaksi kartu kredit memiliki efek positif yang signifikan pada suku bunga

Banyaknya penelitian tentang E-Money dan ECommerce serta Inflasi namun belum ada yang menyatukan pengaruh antar ketiganya sehingga perlu diteliti untuk mendapatkan hasilnyanya

\section{RUANG LINGKUP}

1. Rumusan Masalah

Adapun rumusan masalah pada penelitrian ini adalah:

1) Apakah E Money Berpengaruh terhadap tingkat Inflasi

2) Apakah E Commerce berpengaruh terhadap tingkat Inflasi

2. Batasan masalah

Berdasarkan latar belakang masalah maka penulis membatasi masalah hanya pengaruh e money dan e commerce terhadap tingkat inflasi

3. Rencana hasil

Setelah melihat latar belakang masalah dan fenomena yang terjadi penelitian ini menunjukkan adanya pengaruh e money dan e commerce terhadap tingkat inflasi 


\section{BAHAN DAN METODE}

Bahan penelitian diperoleh dari kuesioner, dan menggunakan metode penelitian deskriptif kuantitatif dan regresi berganda

\subsection{Bahan Memuat Kajian Teori}

Penelitian ini dilakukan dengan menyebarkan kuesioner untuk mengetahui pengaruh E- Money dan ECommerce terhadap Inflasi yang dilakukan dikota Balikpapan

1. Objek penelitian

Objek penelitian ini di lakukan di kota Balikpapan dimana data di ambil secara acak dengan jumlah populasi 50 responden

2. Data Penelitian

Pada penelitian ini digunakan data primer dan skunder yaitu:

1) Data primer adalah data yang didapat secara langsung untuk mendapatkan hasil penelitian

2) Data skunder adalah data yang didapat dari referensi sebagai pendukung penelitian ini

\subsection{Metode Penelitian}

Penelitian ini menggunakan dua metode yaitu:

1. Metode Deskriptif Kuantitatif yaitu utuk menghitung pengaruh e money dan e commerce terhadap tingkat inflasi dan

2. Metode Regresi Linear Berganda yaitu untuk menghubungkan e money dan e commerce secara fungsional

\subsection{Analisis data}

Pada analisis data ini maka digunakan uji hipotesis dengan

1. Uji t ( Uji Parsial)

Digunakan untuk mengetahui hubungan antara $\mathrm{E}$ money dan E Commerce terhadap Tingkat Inflasi Menentukan $\mathrm{H} 0$ dan Ha.

1) $\mathrm{H} 0: \beta 1>0 \mathrm{E}$ Money tidak berpengaruh negatif terhadap tingkat inflasi

$\mathrm{Ha}: \beta 1<0 \mathrm{E}$ Money berpengaruh negatif terhadap Inflasi

2) $\mathrm{H} 0: \beta 2>0 \mathrm{E}$ - Commerce tidak berpengaruh negatif terhadap Inflasi

$\mathrm{Ha}: \beta 2<0 \mathrm{E}-$ Commerce berpengaruh negatif terhadap Inflasi

Dengan pengambilan keputusan

Jika nilai t-statistik > nilai t-tabel maka $\mathrm{H} 0$ ditolak atau menerima Ha Jika nilai t-statistik < nilai t-tabel maka $\mathrm{H} 0$ diterima atau menolak $\mathrm{Ha}$

2. Uji F Statistik

Uji F dikenal dengan uji serentak atau uji model/uji Anova yaitu untuk menguji yang pengaruh E Money dan E Commerce terhadap Tingkat Inflasi dan untuk menguji model regresi yang ada signifikan atau tidak signifikan. Uji $\mathrm{F}$ dapat dilakukan dengan membandingkan F-hitung dengan F-tabel

\section{PEMBAHASAN}

E-money berkembang di Indonesia, dari tahun ketahun penguna E-money semakin meningkat. Hal ini didukung banyaknya munculnya E-Commerce yang menggunakan E-Money dalam transaksi. Dan banyaknya fasilitas umum yang mualai tumbuh dengan pembayaran dengan E-Money.

Banyaknya pihak yang menerbitkan E-Money sehingga perkembangan cukup pesat, money datang dari masyarakat pengguna ponsel yang jauh lebih berpotensi.

E-Money merupakan uang elektronik yang digunakan sebagai alat pembayaran dengan menggunakan media elektronik yaitu menggunakan jaringan internet. Biasa juga disebut Digital currency, Digital Money, digital Cash, Electronic Curency. Electronic Cash.

E-Money biasa digunakan tanpa adanya otorisasi dan tidak dikenakan beban pada bank dan umumnya disukai masyarakat karena mempunyai beberapa manfaat yaitu lebih nyaman dan mudah untuk pemakaiaannya, dapat dilakukan untuk beberapa transaksi, tidak mesti membuka rekening bank, tidak membawa uang tunai, danm mengurangi tingkat uang palsu.

Berdasarkan data Bank Indonesia banyaknya E Money selama bulan February sampai desember 2018 dapat dilihat dari

Tabel 1. Perkembangan E Money Februari September 2018

\begin{tabular}{|l|l|}
\hline Bulan & Jumlah Instrumen \\
\hline Februabri & 103.707 .405 \\
\hline Maret & $109,775,772$ \\
\hline April & $113,837,552$ \\
\hline Mei & $118,650,970$ \\
\hline Juni & $125,182,806$ \\
\hline Juli & $131,806,962$ \\
\hline Agustus & $135,812,593$ \\
\hline September & $142,477,296$ \\
\hline
\end{tabular}

Data diatas menunjukkan bahwa banyaknya EMoney yang beredar selama 8 bulan bertambah terus. Hal ini dapat meningkatkan inflasi apabila nilai pembayaran melebihkan atau mengurangkan nilai aslinya, hal ini disebabkan oleh kemampuan nilai barang yang dibeli dengan harga yang tertera berbeda pada barang tersebut.

E-Commerce merupakan perdagangan yang menggunakan elektronikdimana didalamnya terdapat beberapa aktivitas yang terdiri dari penjualan, pembelian dan pemasaran, dan dalam bertransaksi menggunakan Emoney dan dapat di katakan juga dengan E-Bisnis dimana pada E-Commerce terdapat bisnis yang berkembang baik secara jasa maupun dagang. E Commerce terdiri dari 
1. E commmerce Bussines to bussines yaitu kerjasama yang dilakukan antara pembeli dan penjual yang berkelanjutan dengan menggunakan alat pembayaran E-Money

2. E-Commerce Bussines to customer yaitu bisnis yang biasa dilakukan antar penjual dan pembeli yang berjualan via online

3. E-Commerce Customer to Customer yaitu dimana konsumen menjual kembali kepada konsumen lainnya

4. E-Commerce Customer to Bussines yaitu dimana konsumen mencari produsen untuk barang yang dibutuhkannya

Manfaat E Commerce yaitu mempermudah bertemunya antara pembeli dan penjual tanpa harus ketempat atau pasar dan dapat dilakukan dimana saja maupun kapan saja, Dampaknya adalah berkurangnya tenaga kerja dan retail dikarenakan banyaknya jual beli dapat dilakukan beberapa orang yaitu admin dan pegawai gudang sementara pada pasar atau retail dibutuhkan banyak karyawan.

Berdasarkan Data dari IlmuOne Data bahwa perkembangan E-Commerce di Indonesia adalah Daftar 6 pemain teratas kebetulan memiliki porsi yang imbang antara kategori C2C (Consumer-to Consumer) Bukalapak, Shopee, Tokopedia; dan B2C Business-toConsumer): Blibli, Jd.id, Lazada. Dari penilaian reputasi, masing-masing memiliki angka yang cukup berimbang, Blibli dan Tokopedia mendapati angka tertinggi. Penilaian terhadap reputasi umumnya didasarkan pada kepercayaan konsumen yang terbentuk dari beberapa faktor, di antaranya jaminan produk, kualitas layanan, hingga efektivitas sistem yang disajikan.

JD.id dan Shopee adalah pemain yang paling baru, keduanya memiliki cara berbeda untuk berbaur dalam persaingan dengan top-players yang ada. Shopee misalnya, dengan nilai investasi besar yang didapat dari perusahaan induk Sea (dulunya Garena) mereka memanjakan konsumen dengan beragam diskon produk.

Meleburnya kategori $\mathrm{C} 2 \mathrm{~B}$ dan $\mathrm{B} 2 \mathrm{C}$ juga ditengarai hadirnya "Official Store" di online marketplace-sebagai contoh brand tertentu memiliki tempat khusus di Bukalapak untuk menjual produk dari distributor resminya. Implikasinya justru menguatkan SKU produk yang dimiliki $\mathrm{C} 2 \mathrm{C}$, hal tersebut sekaligus tervalidasi dalam penilaian kelengkapan produk dengan persentase tertinggi didapat oleh Tokopedia.

Namun demikian salah satu keuntungan yang dapat dioptimalkan oleh para pemain B2C ialah seputar pengalaman pelanggan. Beberapa aspek yang mulai dieksplorasi misalnya menekankan pada kualitas produk, peningkatan layanan logistik misalnya Lazada mengakomodasi layanan eLogistics secara mandiri atau bekerja sama dengan layanan on-demand untuk one-daydelivery, opsi pembayaran yang lebih beragam memungkinkan adanya mekanisme seperticash-ondelivery.
Berdasarkan uraian diatas menunjukkan tingkat pengguna E-Commerce sangatlah besar hal ini berkaitan dengan pengguna E-Money dimana pada pembayaran transaksi biasa E-Commerce menggunakan alat pembayaran elektronik.

Inflasi disebutkan dari defenisi bank Sentral republik Indonesia adalah terjadinya kenaikan harga yang secara terus menerus.

Adapun Indikator inflasi adalah berdasarkan international best practice antara lain:

1. Indeks Harga Perdagangan Besar (IHPB).

Harga Perdagangan Besar pada suatu komoditas adalah harga yang terjadi antara produsen dengan pembeli pertama besar dengan jumlah yang besar juga.

2. Indeks Harga Produsen (IHP)

Perubahan harga yang gterjadi pada produksi barang yang mereka produksi.

3. Deflator Produk Domestik Bruto (PDB)

Terjadinya perubahan harga barang baru, barang produksi lokal, barang jadi, dan jasa. Dan berhubungan dengan PDB.

4. Indeks Harga Aset

Pergerakan harga aset diukur dengan indeks harga aset yang beredar dengan tekanan terhadap harga saham dan property. Salah satu aspek yang mempengaruhi tingkat inflasi adalah kestabilan nilai rupiah. Kestabilan nilai rupiah ini mengandung dua aspek, yaitu kestabilan nilai mata uang terhadap

Barang dan jasa, serta kestabilan terhadap mata uang negara lain. Aspek pertama tercermin pada perkembangan laju inflasi, sementara aspek kedua tercermin pada perkembangan nilai tukar rupiah terhadap mata uang Negara lain.

Bank Indonesia pada kebijakan moneter ditujukan pada pengelolaan tekanan harga dari permintaan aggregat relatif pada penawaran barang dan jasa. Dimana tingkat peredaran uang dan tenaga kerja sangat berpengaruh terhadap tingkat inflasi dan pada $\mathrm{E}$ commerce dan E-Money keduanya saling berkaitan antara banyaknya E-Commerce yang menggunakan EMoney dalam pembayaran sehingga mempengaruhi terhadap peredaran uang dan banyaknya tenaga kerja yang harus dilepas karena tidak dibutuhkannya tenaga kerja dalam menjalankan E-Commerce.

Pada E-Money hasil regresi menunjukkan besarnya pengaruh terhadap tingkat Inflasi sebesar 3,39 dengan nilai koefisien 0.153 dan pada uji $t$ E-Money menunjukkan nilai signifikan dengan jumlah nilai $13,28>3,88$ serta signifikan $0,000<0,0005$

E-Commerce Berdasarkan hasil penelitian yang telah dilakukan berpengaruh terhadap inflasi. besarnya pengaruh E-commerce terhadap tingkat inflasi sebesar 63,1 dengan nilai koefisien regresi sederhana bernilai positif yaitu sebesar 0,499 dan uji $t$ E-Commerce menunjukan nilai thitung lebih besar dari pada nilai $\mathrm{t}$ tabel yaitu 7,123> 2,040 serta nilai Sig. $0,000<0,05$. 
Sehingga dapat disimpulkan bahwa Ha diterima dan Ho ditolak artinya E-Commerce dalam penelitian ini memiliki berpengaruh signifikan terhadap tingkat inflasi

\section{KESIMPULAN}

Berdasarkan hasil penelitian bahwa E-Money dan ECommerce berpengaruh terhadap tingkat Inflasi sehingga butuh aturan yang harus diterapkan sehingga perputaran tidak terlalu cepat

\section{SARAN}

Dengan adanya pengaruh E-Money dan E-Commerce terhadap Inflasi maka diharapkan adanya peraturan harga yang tertera dan yang di E-Commerce sama dengan pembayaran yang menggunakan E-money

\section{DAFTAR PUSTAKA}

A.H.G.M. Spithoven, 1995. "Human capital inflation and unemployment", International Journal of Social Economics, Vol. 22 Issue: 5, pp.4-14

Calson-Ohman, Frida .2018. The Effect Of Increased ECommerce On Inflation Sodertorn University, School of Social Sciences, Economics
Nastiti, Nisaulfathona, dkk .2017. Analisis Pengaruh Instrumen Pembayaran Nontunai Terhadap Stabilitas Sistem Keuangan Di Indonesia. Universitas Diponegoro

Peraturan Bank Indonesia Nomor 20/6/Pbi/2018 Tentang Uang Elektronik. https://www.bi.go.id/id/peraturan/sistem pembayaran/Pages/PBI-200618.aspx. (diakses tanggal 01 Nopember 2018)

State of eCommerce Asia Tenggara. 2017 .https://iprice.co.id/insights/mapofecommerce

Sukirno, Sadono. 2008. Makroekonomi Teori Pengantar. Edisi ketiga. Jakarta: P.T Raja Granfindo Persada

Sugiono, 2017 Statistika Untuk Penelitian, Bandung: Alfabeta

Sutawijaya (2012) Pengaruh Faktor-Faktor Ekonomi Terhadap Inflasi Di Indonesia Jurnal Organisasi dan Manajemen, Volume 8, Nomor 2, September 2012, 85-101 